\title{
EVALUASI PELAKSANAAN KEBIJAKAN PROGRAM PENYEDIAAN AIR MINUM DAN SANITASI BERBASIS MASYARAKAT (PAMSIMAS) DI KABUPATEN PURWAKARTA (STUDI KASUS DI DESA CIKADU KECAMATAN CIBATU)
}

\author{
Ida Yati ${ }^{1)}$, Endang Wirjatmi Trilestari ${ }^{2)}$, Ely Sufianti ${ }^{3)}$, Sutarto Mochtar ${ }^{4)}$, Hendrikus Tri Gedeona ${ }^{5)}$, Darti \\ Sugiharti ${ }^{6}$ \\ ${ }^{1}$ Politeknik Sekolah Tinggi Ilmu Administrasi Lembaga Administrasi Negara (STIA LAN) Bandung, Indonesia \\ bundaluthfi04@gmail.com \\ 2,3,4,5 Politeknik Sekolah Tinggi Ilmu Administrasi Lembaga Administrasi Negara (STIA LAN) Bandung, \\ ${ }^{6}$ DC PAMSIMAS Kabupaten Purwakarta, Indonesia
}

\begin{abstract}
ABSTRAK
Program Pamsimas merupakan salah satu program Pemerintah untuk meningkatkan akses jumlah warga miskin perdesaan yang dapat terlayani perbaikan pelayanan fasilitas air minum dan sanitasi serta untuk meningkatkan nilai dan perilaku hidup bersih dan sehat menggunakan pendekatan partisipasi masyarakat. Penelitian ini dilakukan untuk memberikan kontribusi kajian evaluasi Pamsimas dengan tujuan utama mengevaluasi Pelaksanaan Kebijakan Program Pamsimas tahun 2018-2019 di Desa Cikadu Kecamatan Cibatu Kabupaten Purwakarta. Evaluasi pelaksanaan kebijakan program Pamsimas dianalisis dengan menggunakan enam aspek evaluasi program yaitu efektivitas, efisiensi, kecukupan, perataan, responsivitas dan ketepatan. Metode penelitian yang digunakan pendekatan kualitatif dengan strategi penelitian studi kasus. Validasi data diperoleh dari observasi, wawancara, dokumentasi dan studi pustaka. Hasil penelitian menunjukan bahwa pelaksanaan program Pamsimas tahun 2018-2019 di Desa Cikadu Kecamatan Cibatu belum memberikan pengelolaan program Pamsimas dengan optimal sehingga belum bermanfaat secara menyeluruh untuk masyarakat Desa Cikadu Kecamatan Cibatu. Program Pamsimas baru mencapai sebanyak 45 KK dengan jumlah penduduk 132 jiwa dari data awal berdasarkan Rencana Kerja Masyarakat (RKM) yang telah disepakati adalah $322 \mathrm{KK}$, maka pencapaian kinerja pada penyediaan air minum/bersih sangat rendah yaitu baru mencapai $14 \%$. Hambatan yang paling utama mempengaruhi dalam keberhasilan pelaksanaan program Pamsimas Di Desa Cikadu yaitu kurang terjalinnya koordinasi dengan baik antar anggota Pokja AMPL Kabupaten Purwakarta. Kegiatan kolaborasi, peran program Pamsimas sangat penting untuk mendorong SKPD terkait melakukan percepatan pengembangan akses air minum dan sanitasi perdesaan.
\end{abstract}

Kata Kunci: Evaluasi, Pelaksanaan Kebijakan, Program, Pamsimas.

\section{ABSTRACT}

The Pamsimas program is one of the Government programs to increase access to the number of rural poor who can be served by improved drinking water and sanitation facilities and to increase the value and behavior of clean and healthy living using a community participation approach. This research was conducted to contribute to the Pamsimas evaluation study with the main objective of evaluating the implementation of the 2018-2019 Pamsimas Program Policy in Cikadu Village, Cibatu District, Purwakarta Regency. The evaluation of the implementation of the Pamsimas program policy is analyzed using six aspects of program evaluation, namely effectiveness, efficiency, sufficiency, leveling, responsiveness and accuracy. The research method used is a qualitative approach with a case study research strategy. The results show that the implementation of the Pamsimas program in 2018-2019 in Cikadu Village, Cibatu District has not provided optimal management of the Pamsimas program so that it has not been fully beneficial for the people of Cikadu Village, Cibatu District. The Pamsimas program has only reached 45 households with a population of 132 people. From the initial data based on the agreed Community Work Plan (RKM), it is 322 households, so the performance achievement in the 
Kebijakan: Jurnal Ilmu Administrasi

Volume 12, Nomor 2, Juni 2021

E-ISSN: 2656-2820

P-ISSN 1829-5762

provision of drinking /clean water is very low, reaching only 14\%. The most important obstacle affecting the successful implementation of the Pamsimas program in Cikadu Village is the lack of good coordination among members of the WSES Working Group of Purwakarta Regency., the role of the Pamsimas program is very important to encourage related SKPDs to accelerate the development of access to drinking water and sanitation in rural areas.

Keywords: Evaluation of Policy Implementation, Programs, Pamsimas.

\section{PENDAHULUAN}

Air minum dan sanitasi merupakan salah satu kebutuhan dasar bagi keberlangsungan kehidupan manusia. Menyadari akan pentingnya air minum dan sanitasi bagi kehidupan manusia, Pemerintah melaksanakan pembangunan dalam penyediaan air minum dan sanitasi bagi masyarakat sebagaimana tercantum dalam Rencana Pembangunan Jangka Panjang (RPJP) Nasional Tahun 2005-2025. Dalam RPJP tersebut dijelaskan, bahwa pembangunan penyediaan air minum dan sanitasi diarahkan untuk mewujudkan terpenuhinya kebutuhan dasar masyarakat serta kebutuhan sektor-sektor terkait lainnya seperti industri, perdagangan, transportasi, pariwisata dan jasa sebagai upaya mendorong pertumbuhan ekonomi. Pemenuhan kebutuhan tersebut dilakukan melalui pendekatan tanggap kebutuhan (demand responsive approach) dan pendekatan terpadu dengan sektor sumber daya alam dan lingkungan hidup, sumber daya air serta kesehatan.

Sebagai pelayanan publik yang mendasar, pelayanan air minum dan sanitasi merupakan kewenangan Daerah dan menjadi urusan wajib Pemerintah Daerah, maka belanja Daerah harus diprioritaskan untuk mendanai urusan pemerintahan yang terkait pelayanan dasar yang ditetapkan dengan standar pelayanan minimal (SPM)

Penyediaan air untuk memenuhi kebutuhan masyarakat merupakan salah satu agenda penting dalam menjamin kebutuhan dasar masyarakat. Sayangnya meskipun secara potensial ketersediaan air relatif melimpah masih sering dijumpai masyarakat yang mengalami kesulitan dalam mengakses dan memenuhi kebutuhan air bagi kehidupan sehari-hari. Sebaliknya, pada kalangan masyarakat kelas menengah ke atas cenderung tidak mengalami kesulitan dalam memperoleh air bersih karena mereka mempunyai kemampuan sumber daya terutama bidang finansial. Mereka dengan leluasa dan mudah dapat menggunakan air tanah dalam dengan melakukan pengeboran sampai mendapatkan air bersih.

Program Penyediaan Air Minum dan Sanitasi Berbasis Masyarakat merupakan program dan aksi nyata Pemerintah Pusat dan Daerah untuk meningkatkan akses layanan air minum dan sanitasi bagi masyarakat miskin perdesaan dan menciptakan perilaku hidup bersih melalui promosi kesehatan lingkungan dan penyediaan prasarana dan sarana air minum serta sanitasi berbasis masyarakat yang berkelanjutan. Pelaksanaan kegiatan Program PAMSIMAS I secara efektif dimulai pada tahun 2008 dan dilanjutkan dengan program PAMSIMAS II yang berakhir pada tahun 2016, sedangkan PAMSIMAS III dimulai pada tahun 2017 dan berakhir pada tahun 2020 .

Pada tahun 2014 Kabupaten Purwakarta melaksanakan Kebijakan Program Pamsimas. Desa yang menerima Program Pamsimas II berjumlah 4 (Empat) Desa dan Pamsimas II tahun 2015 berjumlah 8 (Delapan) Desa serta pada tahun 2016/2017 Program Pamsimas III berjumlah 17 (Tujuh belas) Desa. Hal ini menunjukan kepedulian Pemerintah terhadap Program Pamsimas. Perkembangan jumlah penerima program Pamsimas dari tahun 2014-2017 di Kabupaten Purwakarta berjumlah 29 (Dua puluh sembilan) Desa.

Sistem penyediaan air minum dengan jaringan perpipaan yang selanjutnya disebut SPAM merupakan salah satu kesatuan sistem fisik dan non fisik dari prasarana dan sarana air minum yang unit distribusinya melalui perpipaan dan unit pelayanannya menggunakan Sambungan Rumah (SR) dan hidran umum. Kriteria air minum yang aman melalui SPAM dengan jaringan perpipaan dan bukan perpipaan terlindungi dengan kebutuhan pokok minimal 60 liter/orang/hari adalah bahwa sebuah Kabupaten/Kota telah memakai SPAM dengan jaringan perpipaan dan bahkan jaringan perpipaan terlindungi.

Sistem Penyediaan Air Minum perdesaan di Kabupaten Purwakarta pada umumnya adalah wilayah yang tidak menggunakan sistem perpipaan PDAM maupun PJT II. Dibangun melalui program pemerintah dengan sumber dana DAK, APBD I/APBD II dan swadaya dari masyarakat desa. SPAM Perdesaan yang 
Kebijakan: Jurnal Ilmu Administrasi

Volume 12, Nomor 2, Juni 2021

E-ISSN: 2656-2820

P-ISSN 1829-5762

menggunakan perpipaan adalah program SPAM perdesaan di desa rawan air, lokasi Pamsimas, maupun swadaya masyarakat. SPAM perdesaan dengan jaringan perpipaan yang terdapat di Kabupaten Purwakarta sebagai berikut:

Tabel 1. Desa yang telah Memiliki SPAM Perdesaan Di Kabupaten Purwakarta

\begin{tabular}{|c|c|c|c|}
\hline No & Kecamatan & Pamsimas & Non Pamsimas \\
\hline 1. & Plered & Gandasoli & $\begin{array}{c}\text { Sempur, Ganda } \\
\text { Mekar }\end{array}$ \\
\hline 2. & Darangdan & Pasirangin, Cilingga & $\begin{array}{l}\text { Sadar Karya, } \\
\text { Pasirangin }\end{array}$ \\
\hline 3. & Maniis & $F$ & Pasir Jambu \\
\hline 4. & Sukatani & Panyindangan & Panyindangan \\
\hline 5. & Jatiluhur & Mekargalih & Cikaobandung \\
\hline 5. & Pondok salam & 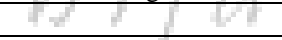 & Bungurjaya \\
\hline 7. & Tegalwaru & Sukamulya & Sukamulya \\
\hline 8. & Wanayasa & Ciawi & Sumurugul \\
\hline 9. & $\begin{array}{l}\text { Babakan } \\
\text { cikao }\end{array}$ & $\begin{array}{l}\text { Cilangkap, } \\
\text { Hegarmanah, } \\
\text { Kadumekar }\end{array}$ & Cigelam \\
\hline 10. & Kiarapedes & $\begin{array}{l}\text { Pusakamulya, Parakan } \\
\text { garokgek, Ciracas, } \\
\text { Ciherang, Margasari }\end{array}$ & \\
\hline 11. & Pasawahan & Kertajaya, Selaawi & \\
\hline 12. & Bojong & $\begin{array}{l}\text { Cibingbin, Cileunca, } \\
\text { Sindangpanon }\end{array}$ & \\
\hline 13. & Cibatu & $\begin{array}{l}\text { Cibukamanah,Cikadu, } \\
\text { Wanawali }\end{array}$ & \\
\hline 14. & Sukasari & Ciririp, Kertamanah & \\
\hline 15. & Campaka & Cisaat & \\
\hline 16. & Bungursari & $\begin{array}{l}\text { Dangdeur, } \\
\text { Karangmukti }\end{array}$ & \\
\hline \multicolumn{2}{|c|}{ Jumlah Desa } & 29 & 11 \\
\hline
\end{tabular}

Sumber: Dinas Kesehatan Kabupaten Purwakarta

Berdasarkan tabel di atas bahwa Desa yang memiliki SPAM Perdesaan di Kabupaten Purwakarta berjumlah 40 Desa yang terdiri dari 29 Desa termasuk Desa Cikadu Kecamatan Cibatu mendapatkan program Pamsimas dan 11 Desa dari program Non Pamsimas.

Desa Cikadu merupakan salah satu Desa di Kabupaten Purwakarta yang mendapatkan program Pamsimas III berdasarkan Keputusan Dirjen Cipta Karya Nomor: 35/KPTS/DC/2017 Tentang Penetapan Desa sasaran program Pamsimas Tahun Anggaran 2017 Tahap I, Desa Cikadu merupakan desa yang belum mendapatkan bantuan untuk pembangunan sarana air minum dan sanitasi yang layak serta mempunyai potensi kekurangan air bersih dan rawan pencemaran air serta kondisi sarana yang ada hanya berasal dari warga/ perorangan. Kondisi ini mengakibatkan akses air minum (SAM 37,75 \%) dan sanitasi (SAN 34, $23 \%$ ) masih rendah, dampak lain dari akses yang masih rendah mengakibatkan penyakit yang diakibatkannya tergolong tinggi dan dilihat dari kapasitas masyarakat yaitu keterampilan dan kemampuan masyarakat terbatas, (RKM Desa Cikadu Kecamatan Cibatu, 2016).

Ketersediaan air yang merupakan potensi yang bisa dikembangkan di Desa Cikadu Kecamatan Cibatu untuk mendukung Program Pamsimas cukup memadai yaitu dengan sistem gravitasi atau pompa dari sumber mata air, sehingga memerlukan kegiatan pembangunan baru, perluasan, atau peningkatan.

Berdasarkan pengamatan awal peneliti, bahwa program Pamsimas di Desa Cikadu Kecamatan Cibatu berupa penyediaan sarana air minum dasar dan penguatan kelembagaan, berupa pelatihan administrasi dan teknik, pelatihan Pola Hidup Bersih dan Sehat (PHBS) serta pelatihan Badan Pengelola Sarana Penyedia Air Minum dan Sanitasi (BPSPAMS). Dalam pelaksanaan program Pamsimas di Desa Cikadu bahwa lembaga pengelola program Pamsimas yang sudah terbentuk tidak bekerja dengan optimal, pengelolaan pendistribusian air yang dipakai oleh masyarakat sebagai penerima manfaat program belum adanya aturan berupa Peraturan 
Kebijakan: Jurnal Ilmu Administrasi

Volume 12, Nomor 2, Juni 2021

E-ISSN: 2656-2820

P-ISSN 1829-5762

Desa yang mengatur tentang iuran tarif pemakaian air dan pemasangan sambungan rumah serta masih rendahnya kesadaran masyarakat atas pemasangan sambungan rumah sendiri.

Selain jaringan perpipaan dari PDAM, pemenuhan kebutuhan air bersih di Kabupaten Purwakarta dilayani pula oleh sumber bukan jaringan perpipaan. Masyarakat yang tidak terlayani air bersih dari PDAM maupun oleh Divisi P3-PJT II, SPAM IKK maupun SPAM Perdesaan dengan memanfaatkan air tanah dan mata air sebagai sumber air bersih dengan membuat sumur gali/sumur bor atau sumber air lainnya/PAH. Dari data Dinas Kesehatan Kabupaten Purwakarta Tahun 2017, tercatat jumlah masyarakat pengguna sarana air bersih bukan jaringan perpipaan di Kabupaten Purwakarta sebanyak 557.840 jiwa dengan prosentase $57 \%$ dari total penduduk Kabupaten Purwakarta. Mayoritas penduduk dengan akses air minum yang bersumber dari bukan jaringan perpipaan yaitu dengan menggunakan sumur gali $42 \%$, sumur bor dengan pompa 8,87 \% dan mata air terlindungi $6,14 \%$., adapun sisanya bersumber dari terminal air dan penampungan air hujan.

Meskipun secara umum, pencapaian akses air minum dan sanitasi di Kabupaten Purwakarta telah cukup tinggi, namun bukan berarti upaya untuk mencapai universal access air minum dan sanitasi tanpa masalah dan hambatan. Sejumlah permasalahan yang dihadapi, beberapa isu yang terjadi pada pelaksanaan program Pamsimas di Kabupaten Purwakarta sebagai berikut:

1. Segi perencanaan, pembangunan sampai monitoring evaluasi masih tertinggal jauh sesuai dengan buku pedoman petunjuk teknis program Pamsimas yang telah dikeluarkan oleh Pemerintah Pusat.

2. Dibidang administrasi bahwa dalam rangka untuk mengetahui kinerja Pamsimas seharusnya dilakukan evaluasi setiap bulan, evaluasi tersebut berdasarkan pada pelaporan pihak BPSPAM selaku pengelola yang bertanggungjawab terhadap Pamsimas sering tidak mengikuti pedoman dan tata cara yang sudah ditentukan.

3. Kekurangan SDM yang kurang kompeten dalam pembukuan dan mindset BPSPAM yang belum mementingkan administrasi menjadi faktor bahwa Pamsimas susah untuk dievaluasi.

4. Pelaksanaan program Pamsimas mengalami ketidaksinkronisasian antara SKPD yang bertanggung jawab. Dinas-dinas terkait, konsultan dan pihak swasta masih tidak memberlakukan Pamsimas sebagai prioritas tugas mereka.

Dengan Banyaknya kekurangan dari pelaksanaan program Pamsimas tersebut yang tidak sesuai dengan pedoman petunjuk teknis merupakan salah satu isu yang harus segera diselesaikan, agar keberlanjutan pelaksanaan program Pamsimas kedepan terus meningkat dan memberikan pelayanan yang optimal serta tepat sasaran yang sesuai dengan prinsip kebijakan AMPL berbasis masyarakat.

\section{METODE}

Pendekatan metode yang digunakan dalam penelitian ini yaitu metode kualitatif. Menurut Bogdan dan Taylor yang dikutip oleh Lexy J. Moleong (2006:3) menyatakan bahwa pendekatan metode kualitatif sebagai prosedur penelitian menghasilkan data deskriptif berupa kata-kata tertulis atau lisan dari orang-orang yang perilakunya diamati. Kriteria metode kualitatif menekankan pada temuan data atau informasi yang bersifat deskriptif dalam berupa keterangan subjek, uraian kata-kata atau kalimat dan bukan data-data yang terbatas pada angka-angka. Pendekatan metode kualitatif dapat digunakan untuk mengungkapkan dan memahami sesuatu dibalik fenomena yang sama sekali belum diketahui dan dapat juga untuk mendapatkan wawasan yang baru sedikit diketahui.

Menurut Sugiyono (2008 : 54) bahwa purposive sampling adalah teknik pengambilan sampel sumber data dengan pertimbangan tertentu. Berdasarkan penjelasan tersebut, maka penelitian ini akan menggunakan teknik Purposive sampling dalam menentukan informan penelitian. Purposive sampling merupakan penentuan informan yang tidak didasarkan atas strata, kedudukan, pedoman atau wilayah tetapi didasarkan pada adanya tujuan dan pertimbangan tertentu yang tetap berhubungan dengan fokus pada penelitian. 
Kebijakan: Jurnal Ilmu Administrasi

Volume 12, Nomor 2, Juni 2021

E-ISSN: 2656-2820

P-ISSN 1829-5762

Tabel 3. Informan penelitian

\begin{tabular}{|c|c|c|}
\hline No & Informan & Peran \\
\hline 1. & Bupati Purwakarta & $\begin{array}{c}\text { Pembina Pokja AMPL Kabupaten } \\
\text { Purwakarta. } \\
\end{array}$ \\
\hline 2. & Koordinator Kabupaten & $\begin{array}{lc}\text { Sebagai } & \text { Koordinator Tim } \\
\text { Evaluasi } & \text { Program Pamsimas }\end{array}$ \\
\hline 3. & Kepala Bappelitbangda & $\begin{array}{c}\text { Sebagai Tim Evaluasi Program } \\
\text { Pamsimas }\end{array}$ \\
\hline 4. & Sekretaris Distarkim & $\begin{array}{l}\text { Sebagai Tim Evaluasi Program } \\
\text { Pamsimas }\end{array}$ \\
\hline 5. & $\begin{array}{l}\text { Kasi Kesling pada } \\
\text { Dinkes } \\
\end{array}$ & $\begin{array}{l}\text { Sebagai Tim Evaluasi Program } \\
\text { Pamsimas }\end{array}$ \\
\hline 6. & $\begin{array}{c}\text { Pemerintahan } \\
\text { Kecamatan/Desa dan } \\
\text { Petugas Saniter UPTD } \\
\text { Puskesmas } \\
\end{array}$ & $\begin{array}{l}\text { Sebagai Tim Evaluasi Program } \\
\text { Pamsimas }\end{array}$ \\
\hline 7. & $\begin{array}{c}\text { KKM dan BP-SPAMS } \\
\text { Desa Cikadu }\end{array}$ & Sebagai Pelaksan Program Pamsimas \\
\hline 8. & Masyarakat & $\begin{array}{c}\text { Sebagai Penerima Manfaat Program } \\
\text { Pamsimas }\end{array}$ \\
\hline
\end{tabular}

Sumber diolah.

Adapun teknik pengumpulan data pada penelitian ini melalui observasi, wawancara, dokumentasi dan studi pustaka. Data-data yang sudah diperoleh dilapangan kemudian akan dianalisis dan diinterprestasi data melalui reduksi dengan mengelompokan hal-hal yang pokok, kemudian disajikan dan akhirnya akan dilakukan penarikan kesimpulan atas jawaban-jawaban yang diperoleh dari informan. Untuk kualitas keabsahan data dengan menggunakan teknik tringulasi dengan cara membandingkan hasil wawancara antara informan yang satu dengan yang lainnya, untuk keperluan pengecekan guna sebagai pembanding terhadap data-data yang sudah diperoleh dilapangan.

\section{PEMBAHASAN}

\section{Kebijakan Publik}

Kebijakan publik merupakan salah satu komponen penting dalam laju perkembangan suatu negara, sebagai respon dan intervensi dari masalah publik sebagai upaya Pemerintah untuk memanajemen kehidupan bersama.

Pengertian kebijakan publik dapat dilihat dari beberapa pendapat para ahli antara lain sebagai berikut:

1. Dalam menghadapi masalah, semua negara relatif sama yang membedakan yaitu bagaimana respon pemerintah terhadap masalah tersebut, respon ini yang disebut sebagai kebijakan publik (Nugroho, 2012:30).

2. Kebijakan publik sebagai pola ketergantungan yang komplek dari pilihan-pilihan kolektif yang saling tergantung, termasuk keputusan-keputusan untuk tidak bertindak yang dibuat oleh badan atau kantor pemerintahan (Dunn, 2003:132).

3. Whatever the governments choose to do or not to do, apapun yang dipilih oleh pemerintah untuk dilakukan atau tidak dilakukan ( Dye, 2002:1);

4. Kebijakan merupakan suatu pedoman untuk bertindak baik untuk melakukan atau tidak melakukan sesuatu guna mencapai suatu tujuan, agar suatu tujuan tersebut dapat tercapai, maka perlu untuk dituangkan kedalam sebuah ketetapan. Sehingga biasanya juga kebijakan tersebut akan berisi perintah maupun larangan, (Mulyadi, 2010:37);

Dari berbagai konsep kebijakan publik yang dikemukakan di atas dapat disimpulkan bahwa kebijakan publik merupakan suatu keputusan yang dibuat dan diimplementasikan oleh pemerintah dari berbagai alternatif pilihan yang ada untuk bertindak atau tidak bertindak sebagai upaya merespon masalah yang ada, sehingga tercapai tujuan yang diharapkan. 
Kebijakan: Jurnal Ilmu Administrasi

Volume 12, Nomor 2, Juni 2021

E-ISSN: 2656-2820

P-ISSN 1829-5762

\section{Evaluasi Kebijakan Publik}

Evaluasi, pemantauan dan peninjauan program merupakan komponen dari operasi yang sedang berlangsung oleh pemerintah. Peneliti mengutif beberapa pendapat dari para ahli mengenai definisi Evaluasi Kebijakan Publik antara lain:

1. Bahwa Operasi program melibatkan 5 (lima) komponen dasar sebagai berikut :

a. A description of the program, ideally covering its legal bassis, its current administrative operating practices, descriptive statistic computed from non financial and financial administrativ data and relevan descriptive statistics computed from other exsrternal data soureces;

b. A description of major interactions of the program with other public program, ideslly including the current legal bases for these interactions and $\mid$ statistics on these interactions computed from administrative data and from other sources.

c. Empirical estimates of the micro level behavioural effects of specified program features;

d. Emperical estimates of macro level behavioural effects of the program;

$e$. Implications of the descriptive review and estimated behavioral effects with respect to the strategic planning or other purposes for which the evaluation of the program was undertaken, (Nakamura dan Warburton, 1998:42-43)

2. Bahwa secara umum istilah evaluasi dapat disamakan dengan penaksiran (appraisal), pemberian angka (rating) dan penilaian (assessment), kata-kata yang menyatakan usaha untuk menganalisis hasil kebijakan dalam arti satuan nilainya. Dalam arti yang lebih spesifik, evaluasi berkenaan dengan produksi informasi mengenai nilai atau manfaat hasil kebijakan, (Dunn, 2003:608).

3. Evaluasi merupakan proses perbandingan antara standar dengan fakta dan analisa hasil, kesimpulannya adalah perbandingan antara tujuan yang hendak dicapai dalam penyelesaian masalah dengan kejadian yang sebenarnya, sehingga dapat disimpulkan dengan analisa akhir apakah suatu kebijakan harus direvisi atau dilanjutkan, (Ndraha, 1989:201).

4. Penilaian (evaluating) evaluasi adalah Proses pengukuran dan perbandingan dari hasil-hasil pekerjaan yang nyatanya dicapai dengan hasil-hasil yang seharusnya, (Danim, 2000:14)

Pendapat di atas dapat diperoleh gambaran bahwa evaluasi adalah suatu kegiatan yang dilakukan untuk mengukur serta membandingkan hasil-hasil pelaksanaan kegiatan yang telah dicapai dengan hasil yang seharusnya menurut rencana. Sehingga diperoleh informasi mengenai nilai atau manfaat hasil kebijakan, serta dapat dilakukan perbaikan bila terjadi penyimpangan di dalamnya.

\section{Fungsi dan Karakteristik Evaluasi Kebijakan Publik}

Menurut Dunn (2003:609-610) mengemukakan bahwa fungsi evaluasi, yaitu pertama, dan yang paling penting, evaluasi memberi informasi yang valid dan dapat dipercaya mengenai kinerja kebijakan. Kedua, evaluasi memberi sumbangan pada klarifikasi dan kritik terhadap nilai-nilai yang mendasari pemilihan tujuan dan target. Ketiga, evaluasi memberi sumbangan pada aplikasi metode-metode analisis kebijakan lainnya, termasuk perumusan masalah dan rekomendasi.

Menurut Bolton (2003:20-24) dalam jurnal Benina veledar, Meliha Basic, Jadranka Kapic (2014:80) bahwa saat membuat indikator kinerja dengan mempertimbangkan kekhasan masing-masing dalam sektor publik maka perlu untuk:

1). Establish operational objectives (objectiv) of each program, focusing on the desired results (outcome) and the target population to which the program relates;

2). Determine the output value (output) needed to achieve the desired results;

3). Determine the link between desired outcomes and out values;

4). Identify all resources (input) required to produce the required output values.

Berdasarkan pernyataan di atas bahwa dalam penilaian kinerja harus menetapkan tujuan operasional, fokus pada hasil yang diharapkan, populasi target yang terkait dengan program, menentukan nilai output, 
menentukan hubungan antara hasil yang diinginkan dan nilai output serta mengidentifikasi semua sumber daya (input) yang diperlukan.

\section{Kriteria Evaluasi Kebijakan Publik}

Mengevaluasi suatu program atau kebijakan publik diperlukan adanya suatu kriteria untuk mengukur keberhasilan program atau kebijakan publik tersebut. Mengenai kinerja kebijakan dalam menghasilkan informasi terdapat kriteria evaluasi sebagai berikut:

\section{Tabel 2.}

Kriteria Evaluasi Menurut Dunn

\begin{tabular}{|c|c|c|}
\hline $\begin{array}{c}\text { Tipe } \\
\text { Kriteria }\end{array}$ & Pertanyaan & Ilustrasi \\
\hline Efektifitas & $\begin{array}{l}\text { Apakah hasil yang } \\
\text { diinginkan telah dicapai? }\end{array}$ & Unit pelayanan. \\
\hline Efisiensi & $\begin{array}{lr}\text { Seberapa banyak } & \text { usaha } \\
\text { diperlukan } & \text { untuk } \\
\text { mencapai hasil yang } \\
\text { diinginkan? }\end{array}$ & $\begin{array}{l}\text { Unit biaya, manfaat } \\
\text { bersih, ratio cost } \\
\text { benefit. }\end{array}$ \\
\hline Kecukupan & $\begin{array}{l}\text { Seberapa jauh pencapaian } \\
\text { hasil yang diinginkan } \\
\text { memecahkan masalah? }\end{array}$ & $\begin{array}{l}\text { Biaya tetap. } \\
\text { Efektivitas tetap. }\end{array}$ \\
\hline Perataan & $\begin{array}{l}\text { Apakah biaya manfaat } \\
\text { didistribusikan dengan } \\
\text { merata kepada kelompok- } \\
\text { kelompok yang berbeda? }\end{array}$ & $\begin{array}{lr}\text { Kriteria } & \text { Pareto. } \\
\text { Kriteria } & \text { Kaldor- } \\
\text { Hicks, } & \text { Kriteria } \\
\text { Rawls. } & \\
\end{array}$ \\
\hline Responsivitas & $\begin{array}{l}\text { Apakah hasil kebijakan } \\
\text { memuaskan kebutuhan, } \\
\text { preferensi, atau nilai } \\
\text { kelompok-kelompok } \\
\text { tertentu? }\end{array}$ & $\begin{array}{l}\text { Konsistesi } \\
\text { dengan survei } \\
\text { warga } \\
\text { negara. } \\
\end{array}$ \\
\hline Ketepatan & 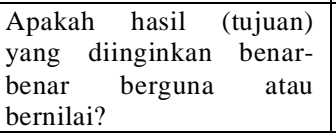 & $\begin{array}{l}\text { Program public } \\
\text { harus merata dan } \\
\text { efisien. }\end{array}$ \\
\hline
\end{tabular}

Sumber: Dunn (2003:610)

\section{Efektivitas}

Menurut pendapat Dunn (2003:429), menyatakan bahwa: "Efektivitas (effectiveness) berkenaan dengan apakah suatu alternatif mencapai hasil (akibat) yang diharapkan, atau mencapai tujuan dari diadakannya tindakan. Yang secara dekat berhubungan dengan rasionalitas teknis, selalu diukur dari unit produk atau layanan atau nilai moneternya"

Menurut pendapat Mahmudi (2005:92) bahwa efektivitas merupakan hubungan antara output dengan tujuan, semakin besar kontribusi (sumbangan) output terhadap pencapaian tujuan, maka semakin efektif organisasi, program atau kegiatan.

Ditinjau dari segi pengertian efektivitas usaha tersebut, maka dapat diartikan bahwa efektivitas adalah sejauhmana dapat mencapai tujuan pada waktu yang tepat dalam pelaksanaan tugas pokok, kualitas produk yang dihasilkan dan perkembangan.

\section{Efisiensi}

Menurut pendapat Dunn (2003:430) bahwa Efisiensi (efficiency) berkenaan dengan jumlah usaha yang diperlukan untuk menghasilkan tingkat efektivitas tertentu. Efisiensi yang merupakan sinonim dari rasionalitas ekonomi, adalah merupakan hubungan antara efektivitas dan usaha, yang terakhir umumnya diukur dari ongkos moneter. Efisiensi biasanya ditentukan melalui perhitungan biaya per unit produk atau layanan. Kebijakan yang mencapai efektivitas tertinggi dengan biaya terkecil dinamakan efisien. 
Kebijakan: Jurnal Ilmu Administrasi

Volume 12, Nomor 2, Juni 2021

E-ISSN: 2656-2820

P-ISSN 1829-5762

\section{Kecukupan}

Kecukupan dalam kebijakan publik dapat dikatakan tujuan yang telah dicapai sudah dirasakan mencukupi dalam berbagai hal. Dunn mengemukakan bahwa kecukupan (adequacy) berkenaan dengan seberapa jauh suatu tingkat efektivitas memuaskan kebutuhan, nilai, atau kesempatan yang menumbuhkan adanya masalah (Dunn, 2003:430).

Dari pengertian di atas dapat disimpulkan bahwa kecukupan masih berhubungan dengan efektivitas dengan mengukur atau memprediksi seberapa jauh alternatif yang ada dapat memuaskan kebutuhan, nilai atau kesempatan dalam menyelesaikan masalah yang terjadi.

\section{Perataan/Kesamaan}

Perataan dalam kebijakan publik dapat dikatakan mempunyai arti dengan keadilan yang diberikan dan diperoleh sasaran kebijakan publik. Menurut Dunn (2003:434) menyatakan bahwa kriteria kesamaan (equity) erat berhubungan dengan rasionalitas legal dan sosial dan menunjuk pada distribusi akibat dan usaha antara kelompok-kelompok yang berbeda dalam masyarakat.

Kebijakan yang berorientasi pada perataan adalah kebijakan yang akibatnya atau usaha secara adil didistribusikan. Suatu program tertentu mungkin dapat efektif, efisien, dan mencukupi apabila biaya-manfaat merata. Kunci dari perataan yaitu keadilan atau kewajaran.

\section{Responsivitas}

Responsivitas dalam kebijakan publik dapat diartikan sebagai respon dari suatu aktivitas. Yang berarti tanggapan sasaran kebijakan publik atas penerapan suatu kebijakan. Menurut Dunn (2003:437) menyatakan bahwa Responsivitas (responsiveness) berkenaan dengan seberapa jauh suatu kebijakan dapat memuaskan kebutuhan, preferensi, atau nilai kelompok-kelompok masyarakat tertentu.

Suatu keberhasilan kebijakan dapat dilihat melalui tanggapan masyarakat yang menanggapi pelaksanaan setelah terlebih dahulu memprediksi pengaruh yang akan terjadi jika suatu kebijakan akan dilaksanakan, juga tanggapan masyarakat setelah dampak kebijakan sudah mulai dapat dirasakan dalam bentuk yang positif berupa dukungan ataupun wujud yang negatif berupa penolakan. Dunn (2003:437) mengemukakan bahwa: kriteria responsivitas adalah penting karena analisis yang dapat memuaskan semua kriteria lainnya (efektivitas, efisiensi, kecukupan, kesamaan) masih gagal jika belum menanggapi kebutuhan aktual dari kelompok yang semestinya diuntungkan dari adanya suatu kebijakan.

\section{Ketepatan}

Dunn (2003:499) berpendapat bahwa kelayakan (Appropriateness) adalah kriteria yang dipakai untuk menseleksi sejumlah alternatif untuk dijadikan rekomendasi dengan menilai apakah hasil dari alternatif yang direkomendasikan tersebut merupakan pilihan tujuan yang layak. Kriteria kelayakan dihubungkan dengan rasionalitas substantif, karena kriteria ini menyangkut substansi tujuan bukan cara atau instrumen untuk merealisasikan tujuan tersebut.

Pamsimas merupakan salah satu program Pemerintah yang bertujuan untuk menciptakan masyarakat hidup bersih dan sehat dengan meningkatkan akses air minum dan sanitasi yang berkelanjutan serta melibatkan masyarakat secara aktif melalui sosialisasi program, pembangunan sarana air bersih, pelaksanaan perilaku Hidup Bersih dan Sehat (PHBS), pembentukan badan pengelola, pemeliharaan dan pengelolaan sarana, dan kesinambungan program Pamsimas.

Efektivitas selalu terkait dengan hubungan antara hasil yang diharapkan dengan hasil yang sesungguhnya dicapai. Berdasarkan hasil penelitian menerangkan bahwa Operasional indikator pada aspek Efektivitas antara lain:

1. Produktivitas (kuantitas dari jasa yang dihasilkan) bahwa manfaat dari pelaksanaan program Pamsimas adalah kemudahan untuk mendapatkan air bersih dan juga meningkatkan derajat kesehatan;

2. Kualitas yang dihasilkan dari program Pamsimas di Desa Cikadu Kecamatan Cibatu sudah memiliki 
Kebijakan: Jurnal Ilmu Administrasi

Volume 12, Nomor 2, Juni 2021

E-ISSN: 2656-2820

P-ISSN 1829-5762

kategori persyaratan air minum yang sesuai dengan Peraturan Menteri Kesehatan Republik Indonesia Nomor 492/Menkes/Per/IV/2010 Tentang Persyaratan kualitas air minum.

3. Motivasi (adanya kekuatan yang muncul dari setiap individu untuk mencapai tujuan), bahwa kebijakan AMPL yaitu pendidikan PHBS sudah dilaksanakan, yang mana masyarakat dan siswa SDN Cikadu merasa termotivasi dengan adanya kegiatan Program Pamsimas yaitu Pemicuan PHBS yang menghasilkan perubahan perilaku BABS yaitu penambahan masyarakat memiliki pasilitas jamban keluarga guna tercapainya tujuan Program Pamsimas dalam akses sarana sanitasi yang layak.

\section{Aspek Efisiensi}

Efektivitas dan efisiensi sangatlah berhubungan. Efisiensi akan terjadi apabila penggunaan sumber daya diberdayakan secara optimal, sehingga suatu tujuan akan tercapai. Program Pamsimas di Desa Cikadu pada tahun 2016 berdasarkan pengajuan proposal dan hasil seleksi Tingkat Kabupaten Purwakarta yang terealisasi pada akhir Tahun Anggaran 2017. Berdasarkan hasil penelitian menerangkan bahwa Operasional indikator pada Aspek Efisiensi antara lain:

1. Adanya target pencapaian waktu bahwa kebijakan AMPL dalam pelaksanaan pembangunan program Pamsimas kurang dilakukannya keterlibatan masyarakat, namun target pencapaian waktu pembangunan sesuai dengan yang telah ditetapkan

2. Tersedianya sumber daya manusi maka dibentuklah lembaga kemasyarakatan yaitu BPSPAM sebagai penanggung jawab pengelolaan program Pamsimas namun tidak berjalan secara optimal.

3. Adanya sumber daya modal, yaitu kontribusi dari masyarakat minimal $20 \%$ dari total pendanaan program Pamsimas di desa dilakukan melaui pengumpulan dana tunai (incash) minimal $4 \%$ dan sumber natural berupa bahan lokal/alam, peralatan dan tenaga kerja (inkind) sebesar $16 \%$.

\section{Aspek Kecukupan}

Dalam evaluasi pelaksanaan kebijakan, perlu melihat sudah seberapa jauh pencapaian hasil yang diinginkan dapat memecahkan masalah. Program harus dapat meringankan masalah di lingkungan masyarakat sehingga kebutuhan masyarakat tidak lagi terhambat. Berdasarkan hasil penelitian bahwa operasional indikator pada aspek kecukuapan antara lain:

1. Kecukupan produktivitas air bersih bahwa kebijakan AMPL pelayanan optimal dan tepat sasaran belum bisa dilaksanakan.

2. Solusi yang dilakukan atas usulan masyarakat antara lain :

a. Penertiban jalur distribusi air;

b. Dibentuknya Peraturan Desa tentang Tarif iuran air;

c. Difungsikan kembali BPSPAM.

\section{Aspek Perataan/Kesamaan}

Faktor biaya dan manfaat adalah dua hal dalam mengukur tingkat pemerataan terhadap suatu kebijakan. Kebijakan yang berorientasi pada pemerataan adalah kebijakan yang akibatnya secara adil didistribusikan. Perataan/kesamaan yaitu pendistribusian biaya dan manfaat yang merata. Berdasarkan hasil penelitian bahwa operasional indikator pada variabel aspek perataan/kesamaan antara lain:

1. Distribusi hasil yang merata yaitu Masyarakat yang merasakan manfaat program baru mencapai $45 \mathrm{KK}$ (14 $\%$ ).

2. Kesamaan manfaat program yang dirasakan masyarakat yaitu belum tercapainya pemerataan yang adil.

Berikut tabel KK yang sudah mencapai akses sarana air minum sampai dengan bulan Nopember 2019 sebagai berikut: 
Kebijakan: Jurnal Ilmu Administrasi

Volume 12, Nomor 2, Juni 2021

E-ISSN: 2656-2820

P-ISSN 1829-5762

Tabel 4.

Jumlah KK Akses Terhadap Sarana Air Minum sampai dengan bulan Nopember 2019

\begin{tabular}{|c|l|c|c|}
\hline No & \multicolumn{1}{|c|}{ RT/RW } & Jumlah KK & Jumlah jiwa \\
\hline 1. & RT 001/RW 001 & 4 & 7 \\
\hline 2. & RT 002/RW 001 & 23 & 64 \\
\hline 3. & RT 003/RW 001 & 8 & 27 \\
\hline 4. & RT 007/RW 003 & 6 & 19 \\
\hline 5. & RT 008/RW 003 & 3 & 12 \\
\hline 6. & RT 009/RW 003 & 1 & 3 \\
\hline & Jumlah & 45 & 132 \\
\hline
\end{tabular}

Sumber: KKM Program Pamsimas Desa Cikadu.

\section{Aspek Responsivitas}

Sebuah kebijakan yang berhasil nampak melalui tanggapan masyarakat yang menanggapi pelaksanaan setelah terlebih dahulu memprediksi pengaruh yang akan terjadi jika suatu kebijakan akan dilaksanakan. Dan juga tanggapan masyarakat setelah dampak kebijakan sudah mulai dapat dirasakan dalam bentuk yang positif berupa dukungan ataupun wujud yang negatif berupa penolakan. Responsivitas yaitu dampak kebijakan terhadap pemuasan kebutuhan preferensi atau kelompok tertentu. Berdasarkan hasil penelitian bahwa operasional variabel aspek Responsivitas antara lain:

1. Adanya tanggapan positif yaitu tanggapan masyarakat akan mendukung terwujudnya program, dan Pemerintah Kabupaten Purwakarta siap membeli lahan milik warga yang memiliki sumber mata air. Hal ini dilakukan sebagai upaya pelestarian serta menjaga keberlangsungan sumber mata air di daerah tersebut.

2. Adanya kritik bahwa dari beberapa desa penerima program Pamsimas belum mencapai target dikarenakan masih minimnya kapasitas sumber daya manusia pelaksana pembangunan penyediaan air minum dan sanitasi di Tingkat Desa dan partisipasi serta gotong royong sudah mulai hilang.

3. Adanya saran bahwa agar Pemerintah Daerah Kabupaten Purwakarta untuk memprioritaskan anggaran penyediaan air minum guna tercapainya tujuan keberlanjutan Program Pamsimas yang merupakan program Nasional dan pengawasan secara berkala oleh Pokja AMPL Kabupaten terhadap BPSPAM yang ada di desa guna untuk menghindari penyalahgunaan akan keberfungsian air.

\section{Aspek Ketepatan}

Ketepatan merujuk pada nilai dari tujuan program dan pada kuatnya asumsi yang melandasi tujuan tersebut. Ketepatan (appropriateness) adalah kriteria yang dipakai untuk menseleksi sejumlah alternatif untuk dijadikan rekomendasi dengan menilai apakah hasil dari alternatif yang direkomendasikan tersebut merupakan pilihan tujuan yang layak (Dunn, 2003:499). Berdasarkan hasil penelitian bahwa operasional pada aspek variabel ketepatan antara lain:

1. Program ditujukan kepada masyarakat yang kurang mampu bahwa Masyarakat yang terlayani berpendapatan rendah.

2. Kesesuaian hasil program dengan tujuan yang diharapkan bahwa tujuan program Pamsimas berkelanjutan belum tercapai, sasaran penerima manfaat baru mencapai $45 \mathrm{KK}$ dari jumlah awal $332 \mathrm{KK}$.

3. Adanya perubahan yang dialami masyarakat yaitu meningkatkan derajat kesehatan dan harga diri dengan termotivasinya memiliki jamban sehat dirumah.

Berdasarkan uraian di atas menunjukan bahwa keterkaitan program Pamsimas dengan kebijakan AMPL berbasis masyarakat mempunyai tujuan yaitu meningkatkan jumlah warga miskin perdesaan yang dapat mengakses perbaikan pelayanan serta fasilitas air minum dan sanitasi serta meningkatkan nilai perilaku hidup bersih dan sehat dalam rangka mempercepat target MDGs pada sektor air minum dan sanitasi. 
Kebijakan: Jurnal Ilmu Administrasi

Volume 12, Nomor 2, Juni 2021

E-ISSN: 2656-2820

P-ISSN 1829-5762

Pengelolaan paska konstruksi di tingkat masyarakat melibatkan kader AMPL, KKM, BP-SPAMS, dan Asosiasi Pengelola SPAMS perdesaan Tingkat Kabupaten. Pengelolaan sistem penyediaan air minum dan sanitasi berbasis masyarakat yang berkelanjutan bertujuan untuk memelihara dan meningkatkan kuantitas, kualitas, kontinuitas, dan keterjangkauan akses penduduk perdesaan terhadap air minum dan sanitasi yang layak dan berkelanjutan.

\section{Hambatan dan upaya dalam Pelaksanaan Kebijakan Program PAMSIMAS}

Pelaksanaan kebijakan bukan hal persoalan yang mudah, apalagi kebijakan yang memiliki cakupan serta pengaruh yang luas menyangkut kelompok sasaran serta daerah atau wilayah yang besar. Realita yang terjadi walaupun kebijakan tersebut mempunyai tujuan yang jelas pasti akan mengalami hambatan dalam implementasinya. Salah satu hal yang penting dalam pelaksanaan kebijakan adalah bagaimana mengenali tingkat kesulitan suatu kebijakan untuk diimplementasikan dan bagaimana agar kebijakan tersebut dapat lebih diimplementasikan sesuai dengan tujuan yang telah ditetapkan.

Berdasarkan temuan hasil di lapangan, hambatan dalam Pelaksanaan program Pamsimas di Desa Cikadu antara lain:

\section{a. Kondisi Sosial Ekonomi Masyarakat.}

Kondisi sosial ekonomi masyarakat menjadi salah satu hambatan dalam pelaksanaan program Pamsimas, karena program Pamsimas bersifat swadaya dan berbasis masyarakat. Masyarakat Desa Cikadu mayoritas ekonominya kurang mampu dengan berlatar belakang berprofesi petani dan berpenghasilan kecil serta berpendidikan rendah, sehingga pemahaman dari hasil sosialisasi program Pamsimas yang bersifat swadaya dan ada kewajiban masyarakat sebagai penerima manfaat masih banyak yang belum memahami. Dengan kondisi tersebut, maka kemampuan masyarakat untuk mengadakan biaya pemasangan sambungan rumah dan meteran air dengan biaya sebesar Rp. 400.000,- sangat rendah sehingga menimbulkan kesempatan oleh pihak yang tidak bertanggungjawab dengan dialihkannya jalur pipa distribusi air. Penyalahgunaan tersebut maka pelaksanaan program Pamsimas di Desa Cikadu belum merata.

Berdasarkan pernyataan di atas, upaya mengatasi hambatan tersebut antara lain:

1. Sosialisasi program Pamsimas dengan memberikan materi sosialisasi yang jelas dan mudah dipahami oleh masyarakat dengan mendatangi langsung dari rumah ke rumah maupun masuk kedalam kegiatan masyarakat seperti pengajian, pertemuan PKK maupun melalui kegiatan penimbangan di Posyandu.

2. Kerjasama dengan pihak BUMDes untuk pengadaan biaya pemasangan SR yang merupakan salah satu aspek pendukung dari pelaksanaan program Pamsimas berkelanjutan. Hal tersebut di atas menunjukan bahwa Pemerintahan Desa Cikadu melaksanakan kebijakan AMPL berbasis masyarak yaitu keberpihakan kepada masyarakat miskin/berpenghasilan rendah.

\section{b. Sumber Dana Finansial}

Sumber dana finansial merupakan salah satu aspek penting dalam sebuah pelaksanaan program. Dalam program Pamsimas terdapat dua macam kegiatan yaitu pembangunan fisik untuk penyediaan air bersih, serta perubahan perilaku masyarakat sesuai dengan perilaku hidup bersih dan sehat. Program Pamsimas bersifat swadaya dimana masyarakat diberikan kewajiban untuk menyediakan dana secara swadaya, selain mendapatkan dana stimulan dari Pemerintah Pusat maupun Daerah. Hambatan yang terjadi pada pelaksanaan program Pamsimas adalah kondisi dan kemampuan ekonomi masyarakat penerima manfaat program yang kurang mampu sehingga tidak bisa mencukupi dana swadaya tersebut yaitu biaya pemasangan SR dan meteran air yang mengakibatkan pemasangan SR untuk pendistribusian air Pamsimas ke masyarakat dan meteran air untuk perhitungan pemakaian air tersebut terhambat.

Berdasarkan pernyataan di atas, upaya mengatasi hambatan tersebut antara lain:

1. Pemerintah Kabupaten Purwakarta telah menyusun Rencana Aksi Daerah Air Minum dan Penyehatan Lingkungan (RAD-AMPL) Tahun 2018-2022 yang diharapkan dapat menjadi acuan bersama seluruh pihak dalam upaya memenuhi keterpenuhan air minum dan sanitasi yang dapat memacu pada peningkatan kesejahteraan masyaraka. 
Kebijakan: Jurnal Ilmu Administrasi

Volume 12, Nomor 2, Juni 2021

E-ISSN: 2656-2820

P-ISSN 1829-5762

2. Peningkatan kapasitas pengelolaan sistem penyediaan air minum dan sanitasi berbasis masyarakat melalui peningkatan kapasitas organisasi non pemerintah, peningkatan dukungan kebijakan anggaran daerah dan pengembangan regulasi yang mengatur penyelenggaraan AMPL.

\section{c. Ketepatan Lokasi Pembangunan Sarana}

Kondisi tofografi dan jumlah debit air yang mampu dihasilkan suatu tempat menjadi faktor penentu lokasi pembangunan sarana program Pamsimas. Lokasi pembangunan sarana air program Pamsimas di Desa Cikadu sudah tepat karena bak penampungan air tersebut berada dekat dengan lingkungan masyarakat, namun dikarenakan tanah tersebut milik salah satu warga masyarakat/bukan tanah wakaf/bukan tanah milik Desa sehingga terjadi penyalahgunaan pemanfaatan air program Pamsimas yang seharusnya digunakan untuk kebutuhan sehari-hari, ini digunakan untuk mengairi air kolam yang mengakibatkan terjadinya pendistribusian air tersebut tidak merata bagi penerima manfaat program yang telah ditentukan sesuai dengan RKM (Rencana Kerja Masyarakat).

Berdasarkan pernyataan di atas, upaya mengatasi hambatan tersebut yaitu dengan Rapat Koordinasi dengan pihak terkait, yaitu Pemerintahan Kecamatan dan Desa sudah melaksanakan kebijakan AMPL berbasis masyarakat yaitu peran pemerintah sebagai fasilitator dalam program Pamsimas yang berkelanjutan guna tercapainya kesejahteraan dan kualitas hidup masyarakat. Hal tersebut sesuai dengan Undang-undang nomor 6 Tahun 29014 Tentang Desa, menjelaskan bahwa tujuan pembangunan desa adalah untuk meningkatkan kesejahteraan dan kualitas hidup masyarakat serta penanggulangan kemiskinan. Adapun lingkup pembangunan desa antara lain pemenuhan kebutuhan dasar dan pembangunan sarana dan prasarana termasuk didalamnya air minum dan sanitasi.

Berdasarkan amanat UU tersebut Pemerintahan Desa mempunyai peran yang sangat penting dalam menyelenggarakan pembangunan ditingkat desa termasuk dibidang air minum dan sanitasi. Sehingga dalam pelaksanaan program Pamsimas ditingkat Desa sangat diharapkan adanya peran dari Pemerintahan Desa untuk mendukung keberhasilan pencapaian tujuan program berkelanjutan.

\section{d. Sumber Daya Manusia}

Fungsi dan tugas utama BP SPAM adalah untuk mengoperasikan dan memelihara sarana air dan sanitasi yang dibangun sehingga memberikan pelayanan yang berkelanjutan pada masyarakat penerima manfaat program Pamsimas. Kelompok Pengelola Sarana Penyediaan air minum dan sanitasi (KP SPAM) Desa Cikadu sudah tidak berfungsi lagi, sehingga sekarang pengelolaan program Pamsimas tersebut dialihkan kepada Koordinator KKM. Hal tersebut dikarenakan kurangnya pemahaman terhadap pengelolaan program Pamsimas. Lemahnya kemampuan sumber daya manusia sebagai KP SPAM Desa Cikadu dalam mengelola sarana program Pamsimas.

Berdasarkan pernyataan di atas, upaya mengatasi hambatan tersebut yaitu Peningkatan Kinerja BP SPAMS merupakan salah satu faktor kunci keberhasilan suatu program Dengan demikian peningkatan kemampuan manajerial pengelola program Pamsimas, perlu mendapatkan perhatian dari para pemangku kepentingan untuk peningkatan kualitas kebijakan dan layanan program Pamsimas.

\section{e. Kelompok Kerja Air Minum dan Penyehatan Lingkungan.}

Pemerintah telah menetapkan Kebijakan Nasional Pembangunan Air Minum dan Penyehatan Lingkungan (AMPL). Untuk menunjang kelancaran pada pelaksanaan Kebijakan Nasional tersebut maka Pemerintah Daerah Kabupaten/Kota dipandang perlu untuk membentuk Kelompok Kerja (Pokja) yang ditetapkan dengan Keputusan Bupati. Pelaksanaan Pokja AMPL di Kabupaten Purwakarta berdasarkan Keputusan Bupati No: 660.02.05/Kep.587-DPKAD/2017 Tentang Pembentukan kelompok kerja air minum dan penyehatan lingkungan. Dalam pelaksanaan tugas pokok hasil dilapangan antara anggota Kelompok Kerja AMPL Kabupaten Purwakarta kurang terjalinnya koordinasi dengan baik sehingga dalam pelaksanaan pembangunan dan perkembangan kegiatan program Pamsimas diantaranya di Desa Cikadu kurang terawasi dalam keberlanjutan program dan mengakibatkan tujuan program yang sudah direncanakan dalam Rencana 
Kebijakan: Jurnal Ilmu Administrasi

Volume 12, Nomor 2, Juni 2021

E-ISSN: 2656-2820

P-ISSN 1829-5762

Kerja Masyarakat (RKM) tidak tercapai.

Berdasarkan pernyataan di atas, upaya mengatasi hambatan tersebut yaitu dukungan aktor pelaksana program Pamsimas sangat dibutuhkan dalam pencapaian tujuan dan sasaran program. Dalam pengelolaan program Pamsimas yaitu Kelompok Kerja (Pokja) AMPL, Pemerintah Daerah membuat langkah yang tepat untuk meningkatkan kinerja lembaga yang ada di Kelompok Kerja (Pokja) AMPL yaitu dengan adanya koordinasi antara anggota Kelompok Kerja (Pokja) AMPL diterapkan secara baik akan mempengaruhi keberhasilan pelaksanaan program Pamsimas.

\section{Rekomendasi}

Untuk mengatasi permasalahan pembangunan paska kontruksi program Pamsimas yang terjadi di Kabupaten Purwakarta terutama di Desa Cikadu Kecamatan Cibatu maka Aspek Penguatan Kelembagaan Pengelolaan Air Minum dan Sanitasi Perdesaan Berbasis Masyarakat meliputi:

a. Penguatan fungsi Panitia Kemitraan pada Pokja AMPL dan Asosiasi Pengelola SPAMS Perdesaan sebagai lembaga yang bertanggung jawab membantu Pemerintah Kabupaten dalam pengelolaan program air minum dan sanitasi perdesaan;

b. Peningkatan kinerja BPSPAMS sebagai pengelola SPAM terbangun dan kegiatan kesehatan di tingkat desa;

c. Penguatan peran Kader Masyarakat untuk AMPL dalam rangka membantu Pemerintahan Desa terkait pemantauan kinerja pengelolaan air minum dan sanitasi.

d. Kerjasama/kemitraan dengan Perusahaan yang ada disekitar Wilayah Kecamatan.

\section{SIMPULAN}

Hasil evaluasi pelaksanaan kebijakan program Pamsimas didasarkan pada enam indikator evaluasi diantaranya: efektivitas, efisiensi, kecukupan, pemerataan, responsivitas dan ketepatan. Semua indikator tersebut tetap saling berhubungan satu sama lainnya, namun indikator responsivitas memiliki nilai yang lebih besar dibandingkan indikator lainnya dalam pelaksanaan program Pamsimas yaitu adanya tanggapan positif, kritik serta saran memperlihatkan respon masyarakat terhadap program Pamsimas, Hambatan yang paling utama mempengaruhi keberhasilan pelaksanaan program Pamsimas Di Desa Cikadu yaitu kurang terjalinnya koordinasi dengan baik antar anggota Kelompok Kerja AMPL Kabupaten Purwakarta. Keberhasilan dalam pemenuhan layanan air minum dan penyehatan lingkungan (AMPL) berbasis masyarakat ditentukan beberapa faktor antara lain: arah dan strategi pembangunan, perencanaan yang dinamis, efektivitas pengelolaan, pelembagaan pembangunan serta koordinasi para pelaku. Khusus mengenai pelembagaan pembangunan, sektor AMPL berbasis masyarakat bersinggungan dengan peran berbagai SKPD yaitu BAPPELITBANGDA, Distarkim, Dinas Lingkungan Hidup, Dinas Pemberdayaan Masyarakat Desa dan lain-lain. Melalui kegiatan kolaborasi, peran program Pamsimas sangat penting untuk mendorong SKPD terkait melakukan percepatan pengembangan akses air minum dan sanitasi perdesaan. Kolaborasi ini menjadi alat untuk koordinasi dan berkegiatan bersama dengan target capaian yang sama, yaitu air minum dan sanitasi. Dengan demikian program Pamsimas sebagai kendaraan atau platform pembangunan air minum dan sanitasi benar-benar dapat dipakai nyata di desa dan Kabupaten.

\section{DAFTAR PUSTAKA}

Bolton, M. (2003), Public sector performance measurement delivering greater Accountability”, Work Study, Vol. 52.No. 1. Pp. 20-24.

Dunn, William N. 2003 Pengantar Analisis Kebijakan Publik Edisi Kedua Yogyakarta:Gadjah Mada University Press

Dye, Thomas R. 2002 Understanding Public Policy, Ten Edition, New Jersey Prentice-Hall. 
Kebijakan: Jurnal Ilmu Administrasi

Volume 12, Nomor 2, Juni 2021

E-ISSN: 2656-2820

P-ISSN 1829-5762

Keputusan Direktur Jenderal Cipta Karya Nomor 35/KPTS/DC/2017 Tentang Penetapan Desa Sasaran Program Penyediaan Air Minum dan Sanitasi Berbasis Masyarakat Tahun Anggaran 2017 Tahap I.

Keputusan Bupati Purwakarta Nomor 660.02.05/Kep.587-BKAD/2017 Tentang Pembentukan Kelompok

Kerja Air Minum dan Penyehatan Lingkungan Kabupaten Purwakarta.

Krech David, Ricard S. Cruthfied dan Egerton L. Ballachey yang dikutip Danim 2004. Motivasi Kepemimpinan dan Efektivitas Kelompok.

Laporan Tahunan STBM Kabupaten Purwakarta.

Moleong, Lexy J 2006, Metodologi penelitian Kualitatif, Bandung: PT Remaja Rosdakarya.

Nakamura, A. O., \& Warburton, W. P. (1998). Performance Measurement in the Public Sector. Canadian Business Economics, 37-48.

Ndraha, Taliziduhu, 1999. Konsep Administrasi dan Administrasi di Indonesia. Jakarta: Bina Aksara.

Nugroho, Riant D. 2012 Public Policy. Jakarta.

Peraturan Menteri Kesehatan Nomor 492/MENKES/PER/IV/2010 Tentang Persyaratan Kualitas Air Minum, 2010, Menkes, Jakarta.

Petunjuk Teknis Pelaksanaan Kegiatan Tingkat Masyarakat Program Pamsimas Tahun 2016.

Profil Kabupaten Purwakarta.

Profil Dinas Kesehatan Kabupaten Purwakarta, 2018.

Profil Desa Cikadu, 2018.

Rencana Pembangunan Jangka Panjang (RPJP) Nasional tahun 2005-2025.

Rencana Pembangunan Jangka Menengah Nasional (RPJMN) tahun 2015-2019 Rencana Kerja Masyarakat, Pamsimas: 2016.

Sugiyono, 2008, Metode Penilitian kuantatif kualitatif dan RAD Bandung: Alfabeta.

Veledar, B., Bašić, M., \& Kapić, J. (2014). Performance Measurement in Public Sector of Transition Countries. Business Systems Research Journal, 5(2), 72-83. https://doi.org/10.2478/bsrj-2014-0011 